\title{
Springsteen, Tradition, and the Purpose of the Artist
}

\author{
William I. Wolff \\ Rowan University
}

\begin{abstract}
In 2012, Bruce Springsteen delivered the keynote address at the South By Southwest Music Conference and Festival. His task was daunting: reconnect authenticity to a traditional approach to creating art. By bringing together ideas on authenticity, creativity, and culture, Springsteen's talk joins a lineage of essays that defend poetry, creativity, and culture, including famous works by William Wordsworth and T.S. Eliot. In this article, I connect Springsteen's ideas to the "folk process," which leads to considering Wordsworth's ideas on the voice of the common citizen and Eliot's ideas on historical tradition. In the end, I consider Springsteen's legacy as cultural ambassador for the arts.
\end{abstract}

"[Springsteen] wears his influences on his sleeve."

- Peter Knobler ${ }^{1}$

In March 1973, in the first major article about Bruce Springsteen, Peter Knobler of Crawdaddy! immediately locates Springsteen's influences as Bob Dylan and Van Morrison. Much of Springsteen's 1974 interview with Paul Williams is about his musical influences, ranging from Dylan to The Yardbirds. In a 1975 edition of Rolling Stone, Dave Marsh describes Springsteen as "the

William I. Wolff has licensed this article under a Creative Commons AttributionNonCommercial-ShareAlike 4.0 International license, 2014. The author would like to thank the anonymous reviewers and journal editors for their considerable time and for pushing him to make his article more thorough and nuanced. Please address correspondence to wolffw@rowan.edu.

${ }^{1}$ Peter Knobler, "Who Is Bruce Springsteen and Why Are We Saying All These Wonderful Things About Him?," Crawdaddy!, March 1973, found in: Racing in the Street: The Bruce Springsteen Reader, ed. June Skinner Sawyers (New York: Penguin Books, 2004), 32.

BOSS: The Biannual Online-Journal of Springsteen Studies 1.1 (2014) http://boss.mcgill.ca/ 
living culmination of 20 years of rock \& roll tradition." 2 Scholars have taken that tradition back even further. Alan Rauch, for example, considers Springsteen's work in terms of nineteenthcentury poetic dramatic monologues. ${ }^{3}$ Jim Cullen locates his discussion of Springsteen's influences in the (lowercase " $r$ ") "republican artistic tradition that was articulated by Emerson, received its first clear expression in Whitman, and was carried through a lineage that includes Twain, Dylan, and [others]." 4 Building on Cullen, Bryan K. Garman notes that Guthrie's influence "has gradually placed [Springsteen] in the lineage of Whitman's working-class hero." 5 Roxanne Harde and Irwin Streight locate Springsteen's themes within those of Shakespeare, and Larry David Smith, Streight, Brent Bellamy, Lisa Foster, and Harde also discuss Springsteen's work within a similar lineage of American authors and singers who have articulated the continuing plight of the working class. ${ }^{6}$

2 Knobler, "Who is Bruce Springsteen"; Paul Williams, "Lost in the Flood," Backstreets: Springsteen, The Man and His Music by Charles R. Cross and the editors of Backstreets magazine, in Racing in the Street, 40-42; Dave Marsh, "Bruce Springsteen: A Rock 'Star Is Born,'” Rolling Stone, September 25, 1975, in Racing in the Street, 51.

3 Alan Rauch, "Bruce Springsteen and the Dramatic Monologue," American Studies 29:1 (1988): 29-49.

${ }^{4}$ Jim Cullen, Born in the USA: Bruce Springsteen and the American Tradition (New York: HarperPerennial, 1998), xvi.

${ }^{5}$ Bryan K. Garman, A Race of Singers: Whitman's Working-Class Hero from Guthrie to Springsteen (Chapel Hill: University of North Carolina Press, 2000), 196.

${ }^{6}$ Irwin Streight and Roxanne Harde, "Introduction: The Bard of Asbury Park," in Reading the Boss: Interdisciplinary Approaches to the Works of Bruce Springsteen, eds. Roxanne Harde and Irwin Streight (Lanham, Maryland: Lexington Books, 2010), 1-20; Larry David Smith, Bob Dylan, Bruce Springsteen, and American Song (Westport, Connecticut: Praeger, 2002); Irwin Streight, “The Flannery O'Connor of American Rock," in Reading the Boss, 53-75; Brent Bellamy, "Tear into the Guts:

BOSS: The Biannual Online-Journal of Springsteen Studies 1.1 (2014) 
Missing from these discussions is an exploration of Springsteen's traditional approach to writing. That is, how his approach to composing exists within a history of artists discussing composing processes. The impetus for my discussion is Springsteen's South By Southwest Music Conference and Festival (SXSW) keynote address, delivered on March 15, 2012, in Austin, Texas. In his address Springsteen discusses "the genesis and power of creativity, the power of the songwriter, or let's say composer, or just creator" in an age he describes as "post-authentic," in which "authenticity is a house of mirrors." 7 While many in the media called his keynote a "history lesson," Springsteen's task is larger and the implications of his ideas more far-reaching. ${ }^{8}$ A keynote address can be considered what sociologists Jaber F. Gubrium and

Whitman, Steinbeck, Springsteen, and the Durability of Lost Souls on the Road," Canadian Review of American Studies 41:2 (2011): 223-43; Lisa Foster, "Populist Argumentation in Bruce Springsteen's The Rising," Argumentation \& Advocacy 48:2 (2011): 61-80; Roxanne Harde, “'Living in Your American Skin': Bruce Springsteen and the Possibility of Politics," Canadian Review of American Studies 43:1 (2013): 125-44.

7 “Bruce Springsteen's SXSW 2012 Keynote Speech," NPR.org, March 18, 2012, Austin, Texas; accessed June 2014, http://www.npr.org/2012/03/16/148778665/ bruce-springsteens-sxsw-2012keynote-speech

8 Thomas Connor, "SXSW Keynote: Bruce Springsteen Gives Musical History Lesson, Celebrates Woody Guthrie Centennial," Chicago Sun-Times, March 15, 2012, accessed June 2014, http://blogs.suntimes.com/music/2012/03/sxsw_keynote_bruce_springsteen. html; Brandon Griggs, “Professor Springsteen's Rock 'N' Roll History Lesson at SXSW," CNN, March 16, 2012, accessed June 2014, http://www.cnn.com/2012/03/15/showbiz/springsteen-keynotesxsw / index.html; Chris Talbott, "Springsteen Gives Music History Lesson at SXSW," Yahoo! News, March 16, 2012, accessed June 2014, http:/ / news.yahoo.com/springsteen-gives-music-history-lesson-sxsw191801096.html.

BOSS: The Biannual Online-Journal of Springsteen Studies 1.1 (2014) 
James A. Holstein call a "discursive environment," a space that "provide[s] choices for how we articulate our lives and selves. Discursive environments are interactional domains characterized by distinctive ways of interpreting and representing everyday life, of speaking about who and what we are." 9 In this discursive environment, Springsteen adopts the role of a literary critic to interpret and defend a particular approach to the creation of art grounded in "your teachers, your influences, your personal history." 10 By bringing together ideas on authenticity and creativity under one heading within the context of a time when popular music has become "a new language, cultural force, [and] social movement," Springsteen's talk joins a lineage of essays that defend poetry, creativity, and culture, dating back to Aristotle's "The Art of Poetry" and including work by Philip Sidney, William Wordsworth, Percy Shelley, Ralph Waldo Emerson, Matthew Arnold, T.S. Eliot, Flannery O'Connor, Adrienne Rich, Susan Sontag, Jonathan Latham, and others. ${ }^{11}$

In this article, I locate Springsteen's discussion of the creation of art within a lineage of artists discussing the processes of composing. First, I connect Springsteen's discussions on influence to country and folk music. Proponents of these two genres have employed similar claims about the authenticity of common language and what Pete Seeger has described as "links in a chain.

\footnotetext{
9 Jaber F. Gubrium and James Holstein, "From the Individual Interview to the Interview Society," in Postmodern Interviewing, ed. Jaber F. Gubrium and James A. Holstein (Thousand Oaks: SAGE Publications, Inc, 2003), 44.

${ }^{10}$ Springsteen, "Bruce Springsteen's SXSW 2012 Keynote Speech."

${ }^{11}$ Springsteen, "Bruce Springsteen's SXSW 2012 Keynote Speech."
}

BOSS: The Biannual Online-Journal of Springsteen Studies 1.1 (2014) 
All of us [musicians], we're links in a chain."12 I then contextualize Springsteen's observations within an extended discussion of Wordsworth's Romantic theme of the authentic voice of the common citizen and Eliot's Modern theme of the importance of literary tradition, focusing on Springsteen's We Shall Overcome: The Seeger Sessions. Wordsworth's 1802 "Preface to Lyrical Ballads" and Eliot's 1921 essay "Tradition and the Individual Talent" are instructive for contextualizing Springsteen's approach to writing and his ideas on the composing process as articulated in his SXSW address and elsewhere. Bringing Wordsworth and Eliot together may surprise some, especially because of Eliot's rejection of Romanticism and his admonitions against emotion and personality, which are two of Wordsworth's main approaches. Springsteen, however, coalesces Wordsworth's call for the poet "to choose incidents and situations from common life, and to relate or describe them, throughout, as far as was possible in a selection of language really used by men" with Eliot's call for the poet to "procure a consciousness of the past and [to] continue to develop this consciousness throughout his career."13 Building on the themes of tradition and authenticity, I conclude by considering Springsteen as heir of Guthrie's and Seeger's legacies. In the end, I challenge Springsteen to more fully embrace practices that separate him from corporate labels if he is to embody fully what is becoming his developing role as cultural ambassador for the arts.

\footnotetext{
12 Paul Zollo, Songwriters On Songwriting: Revised And Expanded (New York: Da Capo Press, 2003), 12.

${ }^{13}$ William Wordsworth, Selected Poems and Prefaces, ed. Jack Stillinger (Boston: Houghton Mifflin, 1965), 446; T.S. Eliot, "Tradition and the Individual Talent," in Selected Prose, ed. John Hayward (Harmondsworth, Middlesex: Penguin, 1955), 25.
}

BOSS: The Biannual Online-Journal of Springsteen Studies 1.1 (2014) 


\section{Springsteen's SXSW Keynote and the Folk Process}

In his SXSW keynote, Springsteen uses his podium to argue in defense of a process of creating meaningful work:

I'd like to talk about the one thing that's been consistent over the years: the genesis and power of creativity, the power of the songwriter, or let's say composer, or just creator. So whether you're making dance music, Americana, rap music, electronica; it's all about how you are putting what you do together. The elements you're using don't matter. Purity of human expression and experience is not confined to guitars, to tubes, to turntables, to microchips....

We live in a post-authentic world. And today authenticity is a house of mirrors. It's all just what you're bringing when the lights go down. It's your teachers, your influences, your personal history. And at the end of the day, it's the power and purpose of your music that still matters. ${ }^{14}$ Springsteen chooses a daunting task for any orator: to reconnect authenticity to a traditional approach to creating art. His concerns are similar to those of Philip Sidney in 1595: to defend his art to a society that openly questioned the authenticity of poetry. In "The Defense of Poesy," Sidney advocates for poetry and poets against charges that writing poetry is a waste of time, that poems are full of lies and "infect us with pestilent desires." 15 In response, Sidney argues for the importance of poetry in terms of how poets interpret and represent the worlds around them: "Only the poet, disdaining to be tied to any such subjection, lifted up with the vigor of his own invention, doth grow, in effect, into another nature, in making

14 Springsteen, "Bruce Springsteen's SXSW 2012 Keynote Speech.”

15 Philip Sidney, "The Defense of Poesy," in The North Anthology of English Literature Vol. 1, ed. M. H. Abrams, (New York: W. W. Norton \& Company, 1993), 492-493.

BOSS: The Biannual Online-Journal of Springsteen Studies 1.1 (2014) 
things ... better than nature bringeth forth..."16 For Sidney, "Poesy is of all human learnings the most ancient and of most fatherly antiquity, as from whence other learnings have taken their beginnings..."17 Springsteen similarly approaches his defense by locating popular music within a history of contemporary music before asserting that "[p]op's become ... a series of new languages, cultural forces, and social movements that have inspired and enlivened the second half of the twentieth century, and the dawning years of this one." 18 It is, however, also a time that has seen the fragmentation of music in dozens of genres and sub-genres (which Springsteen relishes listing) and the erosion of personal and public authenticity. Springsteen opens his talk by expressing ambivalence over the word "keynote"; he fears it means there is a singular view of contemporary music. He strives to overcome genre and philosophical divides by focusing on the one thing that might unite all artists: the process of creating. His address implies that understanding the creative process, rather than the technologies of production or genre distinctions, is of primary importance for instilling a level of authenticity in what artists do and how they are perceived.

Springsteen's goal is to defend an approach to creativity that depends heavily on influence: "its your teachers, your influences, your personal history" that will make an artist authentic in a postauthentic world. To do that, Springsteen structures his artistic development as a journey of discovery of the rock, soul, pop, country, and folk influences that have helped him to evaluate his

\footnotetext{
16 Sidney, "The Defense of Poesy," 482-483.

17 Sidney, "The Defense of Poesy," 492.

18 Springsteen, "Bruce Springsteen's SXSW 2012 Keynote Speech."
}

BOSS: The Biannual Online-Journal of Springsteen Studies 1.1 (2014) 
personal history of growing up poor in small town New Jersey and the socio-economic values he considers sedimented in America. He then presents an image of that America back to the audience as a way of working through his questions about what he is coming to understand. Springsteen begins his narrative with Elvis, whom Springsteen remembers seeing on The Ed Sullivan Show in 1956. A week later, Springsteen's six-year-old fingers were wrapped around the neck of a rented guitar. But even before Elvis changed the world of young Bruce, Springsteen brings the audience further back, back to a time when he was too young to realize the influence music was having on his life, while eating breakfast, listening to doo-wop coming from his mother's radio:

the most sensual music ever made, the sound of raw sex, of silk stockings rustling on backseat upholstery, the sound of the snaps of bras popping across the [U.S.A.], of wonderful lies being whispered into Tabu-perfumed ears, the sound of smeared lipstick, untucked shirts, running mascara, tears on your pillow, secrets whispered in the still of the night, the high school bleachers and the dark at the YMCA canteen. ${ }^{19}$ Doo-wop was the stuff of 1950's teen-agers' dreams and desires. And those dreams and desires "dripped from radios" in the rustic spaces in which he found himself: "the gas stations, factories, streets and pool halls - the temples of life and mystery in my little hometown." 20 On stage Springsteen begins strumming his guitar and singing, "Ooooo whooo. Whooo. Whooo." He says, "Don't that make you want to kiss somebody?" and segues into strumming and singing the opening lines of "Backstreets." Then, commenting on the two rhythms he just strummed, Springsteen concludes, "It all

19 Springsteen, “Bruce Springsteen's SXSW 2012 Keynote Speech.”
20 Springsteen, "Bruce Springsteen's SXSW 2012 Keynote Speech.”

BOSS: The Biannual Online-Journal of Springsteen Studies 1.1 (2014) 
comes from the same place." And that musical place for Springsteen has been with him since he was a child. Elsewhere, Springsteen told Will Percy, "I didn't grow up in a community of ideas - a place where you can sit down and talk about books, and how you read them, and how they affect you." 21 In Springsteen's household there were no books, nor appreciation for books or the development of ideas. ${ }^{22}$ In this formative vacuum, as Springsteen has stated, "the importance of rock \& roll was just incredible. It reached down into all those homes where there was no music or books or any kind of creative sense, and it infiltrated the whole thing." 23 In 1981, he told an audience in England that the voices coming out of the radio "held out a promise, and it was a promise that every man has a right to live his life with some decency and respect." 24 Springsteen's education came in the form of records, a form of rebellion he later described in "No Surrender."

After leading the SXSW audience through his early rock education, from Roy Orbison to Johnny Cash to Phil Spector's wall of sound, Springsteen comes to The Animals, who were to him "a revelation $\ldots$ the first records with full blown class consciousness." 25 He then starts to play The Animals' "We Gotta Get Out of this Place," ending with

\footnotetext{
21 Will Percy, "Rock and Read: Will Percy Interviews Bruce Springsteen," DoubleTake, 1998, in Talk About A Dream: The Essential Interviews of Bruce Springsteen, ed. Christopher Phillips and Louis P Masur (New York: Bloomsbury Press, 2013), 221.

22 Dave Marsh, Glory Days: Bruce Springsteen in the 1980s (New York: Pantheon, 1987), 35-36.

23 Paul Nelson, "Springsteen Fever," Rolling Stone, 1978, accessed June 2014, http://www.rollingstone.com/music/news/springsteen-fever-20120919.

${ }^{24}$ Marsh, Glory Days, 36.

${ }^{25}$ Springsteen, "Bruce Springsteen's SXSW 2012 Keynote Speech."
}

BOSS: The Biannual Online-Journal of Springsteen Studies 1.1 (2014) 
We gotta get out of this place

If it's the last thing we ever do

We gotta get out of this place

Girl, there's a better life for me and you.

Yes, I know it's true.

Upon finishing, Springsteen confesses, "That's every song I've ever written. Yeah. That's all of them. I'm not kidding, either. That's 'Born to Run,' 'Born in the [U.S.A.],' everything I've done for the past 40 years, including all the new ones. But that struck me so deep. It was the first time I felt I heard something come across the radio that mirrored my home life, my childhood." 26 Later, Springsteen comes back to the influence of The Animals: "'Badlands,' 'Prove it all Night' - Darkness was filled with The Animals, you know? Youngsters, watch this one. I'm gonna tell you how it's done, right now." Springsteen plays the beginning of "Don't Let Me Be Misunderstood" and segues into the guitar riff from "Badlands" and exclaims, "It's the same fucking riff, man! Listen up, youngsters: this is how successful theft is accomplished, all right?" 27 Springsteen instructs the audience on the multi-genre influences found in his songs that blend the emotional and sexual rawness of 1950s doo-wop with the class consciousness of 1960s rock. He adds to his genre influences by bringing the audience back through the sensuality of soul to the grit of country to the immediacy of Woody Guthrie. He says at one point, "These men and women, they were and they remain my masters." 28 The emotion and the grit coalesce in Springsteen and his open acknowledgement of not just the importance of prior music, but

\footnotetext{
26 Springsteen, "Bruce Springsteen's SXSW 2012 Keynote Speech."

27 Springsteen, "Bruce Springsteen's SXSW 2012 Keynote Speech."

28 Springsteen, "Bruce Springsteen's SXSW 2012 Keynote Speech."
}

BOSS: The Biannual Online-Journal of Springsteen Studies 1.1 (2014) 
what he calls "theft" - and we might now call "remix" - leads to the significant intertextuality on display in his work. ${ }^{29}$ In "Intertextuality and the Discourse Community," James Porter uses the metaphor of an archaeologist to describe how writers piece together prior texts to create new meaning: "Not infrequently, and perhaps ever and always, texts refer to other texts and in fact rely on them for their meaning. All texts are interdependent: We understand a text only insofar as we understand its precursors. This is the principle we know as intertextuality." 30 Springsteen's music and lyrical themes rely heavily on those of his so-called masters and argue for a composing process that openly acknowledges influences. When Springsteen inherits and incorporates past work, he is also preserving both the music and its lineage.

That is the essence of the "folk process," a term coined by Pete Seeger's father, Charles, to describe "a process which has been going on for thousands of years. Ordinary people changing old things to fit new situations." 31 The folk process is similar to how Porter describes the social life of texts: "Authorial intention is less significant than social context; the writer is simply a part of a discourse tradition, a member of a team, and a participant in a community of discourse that creates its own collective meaning." 32 By employing elements of intertextuality and by adopting a folk

\footnotetext{
${ }^{29}$ Brett Gaylor, RiP! A Remix Manifesto, Documentary (EyeSteelFilm, 2008), accessed June 2014, http:/ / www.hulu.com/watch/88782/rip-a-remixmanifesto.

30 James E. Porter, "Intertextuality and the Discourse Community," Rhetoric Review 5:1 (1986): 34,

${ }^{31}$ Pete Seeger, Where Have All the Flowers Gone: A Singalong Memoir, ed. Michael Miller and Sarah A. Elisabeth (New York: SingOut!, 2009), 15; 85.

32 Porter, "Intertextuality and the Discourse Community," 35.
}

BOSS: The Biannual Online-Journal of Springsteen Studies 1.1 (2014) 
process even before he became so heavily influenced by the work of Hank Williams and Woody Guthrie in the late 1970s and early 1980s and Pete Seeger in the late 1990s, Springsteen shows himself to be an artist with not just a historical consciousness but also an overt praxis of incorporating the ideas and the work of his forebears. An awareness of the past is a significant part of what he believes makes music authentic; his subjects and characters are grounded in the history of music and literature, the socio-economic struggles of the past, and the traumas of the present. Like his folk teachers, he brings these all together through an awareness of the past in songs that speak the language of ordinary people.

Pete Seeger teaches that European academics coined the phrase "folk song" in the nineteenth century "to mean the music of the peasant class, ancient and anonymous. In the U.S.A., it was used by people like John Lomax, who collected songs of cowboys and lumberjacks, coal miners and prisoners in southern chain gangs." 33 With that definition, one could certainly argue that Springsteen's songs have always been folk; though not peasants, his characters have been those hardworking anonymous people laboring in factories and foundries, carwashes and construction. Indeed, John Hammond signed Springsteen as a folk musician based on his Dylanesque folk lyrical prowess, though it wasn't until Springsteen began listening to Hank Williams, Woody Guthrie, and the Folkways recordings that he began to see himself as part of their lineage. ${ }^{34}$ In Songs, he describes "The River" as being his "narrative folk voice-just a guy in a bar telling his story to the

\footnotetext{
${ }^{33}$ Seeger, Where Have All the Flowers Gone, 16.

${ }^{34}$ Marsh, Glory Days, 112.
}

BOSS: The Biannual Online-Journal of Springsteen Studies 1.1 (2014) 
stranger on the next stool." 35 Talking about Nebraska in 1984 with Roger Scott and Patrick Humphries, Springsteen describes the lyrics as folk: "What made the record work [was] the sound of real conversation ... like you were meeting different people, and they just told you what had happened to them, or what was happening to them. So, you kind walked for a little bit in their shoes." 36 As Irwin Streight suggests, the songs on Nebraska tell "stories with an attention to small revealing details and with a depth and compression of characterization that matches the masters of the short story genre." 37 Consider the opening lines of "Johnny 99":

Well they closed down the auto plant in Mahwah late that month

Ralph went out lookin' for a job but he couldn't find none He came home too drunk from mixin' Tanqueray and wine He got a gun shot a night clerk now they call'm Johnny 99 In just four lines Springsteen presents Ralph's past, present, and future. The song opens with the closing of the actual Mahwah Ford plant in 1980, providing a historical context that sets the tone for the entire song. Springsteen shows Ralph's despair and, using mostly monosyllabic words, discusses the events that will, just six verses later, lead to Ralph demanding he be executed. Springsteen gives similar levels of personal detail and decay in earlier songs like "Growin' Up," "Thunder Road," and "Racing in the Street."

Springsteen's characters, their stories, their suffering, and their voices are of utmost importance for him. They exist within a lineage of country music, a genre with Hank Williams as its leader

\footnotetext{
35 Bruce Springsteen, Songs (New York: Avon Books, 1998), 100.

36 Roger Scott and Patrick Humphries, Interview with Bruce Springsteen, from Hot Press, November 2, 1984, in Talk About A Dream, 132.

37 Streight, “The Flannery O'Connor of American Rock," 55.
}

BOSS: The Biannual Online-Journal of Springsteen Studies 1.1 (2014) 
that, as Charles Lindholm writes, became "the music of the new rootless American working class. It articulated a lament of the betrayed wanderer, searching for love and settling for lust, far from home, working hard, drinking hard and fighting hard, wishing for salvation, and without much hope of ever finding it." 38 In his keynote address, Springsteen says,

In country music, I found the adult blues, the working men's and women's stories I'd been searching for, the grim recognition of the chips that were laid down against you ... Country, by its nature, appealed to me. Country was provincial, and so was I. I was not downtown. I wasn't particularly Bohemian or hipster. I was kind of hippy-bycircumstance, when it happened. But I felt I was an average guy, with a slightly above average gift. ${ }^{39}$

The very provinciality of country felt authentic to Springsteen; he identified with what he heard. At first, his endeavor was close to replication. Marsh suggests that the "Nebraska demos had the quality and stillness associated with the great Library of Congress folk recordings of the 1930s and 1940s." ${ }^{40}$ But that replication remained true to the original recordings, remediating an authenticity that signified rustic roots in stories crafted to depict a singular version of working-class American life. Later, he was able to put folk stories into more formal rock contexts on Born in the U.S.A. and Wrecking Ball. On Wrecking Ball, for example, Springsteen harnesses prior work to suggest that the past and present are inextricably connected. When discussing how he

38 Charles Lindholm, Culture and Authenticity, (Malden, Massachusetts: WileyBlackwell, 2007), 31.

39 Springsteen, "Bruce Springsteen's SXSW 2012 Keynote Speech."

${ }^{40}$ Marsh, Glory Days, 112.

BOSS: The Biannual Online-Journal of Springsteen Studies 1.1 (2014) 
composed the songs for Wrecking Ball in a wide-ranging interview with the Paris media in 2012, Springsteen revealed

those are voices from history and other sides of the grave. If you listen to [Wrecking Ball], I use a lot of folk music. There's some Civil War music. There's gospel music. There are '30s horns in "Jack of All Trades." That's the way I used the music-the idea was that the music was going to contextualize historically that this has happened before: It happened in the 1970s, it happened in the '30s, it happened in the 1800s ... it's cyclical. Over, and over, and over, and over again. So I try to pick up some of the continuity and the historical resonance through the music. ${ }^{41}$

For Springsteen, music is an artifact of the time period in which it was created. Springsteen samples prior work in five songs on Wrecking Ball, building layers of history into songs about contemporary concerns. "We Are Alive" starts with 20 seconds of a needle tracking through a groove, sonically alerting the listener to the importance of past forms of musical production and simultaneously connecting the song to the rustic audio tracks on Nebraska (and by extension the Folkways recordings). The folk connection is reinforced by sampling the mariachi-style horns from Johnny Cash's "Ring of Fire," written by June Carter and Merle Kilgore, and originally released by Anita Carter in 1963 on Folk Songs Old and New. The track's "ring" reinforces the conceit of cyclicality found in "We Are Alive," most especially in the song's protagonists' Lazarus-like rising from the dead. The track's "fire" spreads to Springsteen's chorus: "We are alive / And though our bodies lie alone here in the dark / Our spirits rise / To carry the

41 Bruce Springsteen, "An American in Paris" (interview), March 2, 2012, accessed June 2014, http:/ / backstreets.com/paris.html .

BOSS: The Biannual Online-Journal of Springsteen Studies 1.1 (2014) 
fire and light the spark / To stand shoulder to shoulder and heart to heart." The chorus emphasizes the continuing legacy of past struggles for fair wages and respect. The song challenges the listener to research the historical references and think through the complexity of the samples and sonic layers. In order to fully appreciate many of the songs on Wrecking Ball, one must learn about and listen to the songs that Springsteen uses to provide "continuity and historical resonance." Wrecking Ball is an album that holds its full meaning through discovering and recovering an ecology of music and histories Springsteen has layered and written into it.

\section{Springsteen, Wordsworth, Eliot, and the Role of the Writer}

Music producer Mark Hagen once asked Springsteen how he is able to compose lyrics that Hagen felt deeply and personally connected to. Springsteen responded, “That's the writer's job. The writer collects and creates ... moments from out of his own experience and the world that he sees around him. Then you use your imagination and put those things together, and you present that experience to your audience." 42 Springsteen's response unconsciously echoes T.S. Eliot in "Tradition and the Individual Talent": "The poet's mind is in fact a receptacle for seizing and storing up numberless feelings, phrases, images, which remain there until all the particles which can unite to form a new compound are present together." 43 Both Springsteen and Eliot echo William Wordsworth's definition of his own task as a poet in

\footnotetext{
42 Mark Hagen, Interview with Bruce Springsteen from Mojo, January 1999, in Talk About a Dream, 255-256.

${ }^{43}$ Eliot, "Tradition and the Individual Talent," 27.
}

BOSS: The Biannual Online-Journal of Springsteen Studies 1.1 (2014) 
"Preface to Lyrical Ballads": "The principal object ... was to choose incidents and situations from common life, and to relate or describe them, throughout, as far as was possible." 44 All three writers describe a composing process situated in the spaces they see and experiences they have. This process is called "situated cognition" and, according to Margaret A. Syverson, "refers to the fact that cognitive processes are always embedded in specific social, cultural, and physical-material situations, which determine not only how cognitive processes unfold but also the meanings they have for participants." 45 Syverson, for example, has shown how the poems of Charles Reznikoff were composed through an evolving ecology of texts: notebooks, letters, personal experiences, the experiences of others, books, and so on. ${ }^{46}$ In his poetry, Wordsworth drew heavily on his walks and the emotions he had during them, often looking to his sister Dorothy's journal for inspiration years after an event or encounter. Each of Eliot's Four Quartets is inspired by places important to him and his family, and parts of The Waste Land describe his exact path through London on the way to work. Similarly, Springsteen has collected spaces around him and represented them, first in his voluminous notebooks and later in songs told through the voices of others very much as Wordsworth does in his ballads and Eliot does in his dramatic monologues.

Though there may be autobiographical elements in Springsteen's songs (and in Eliot's and Wordsworth's poems), the stories told and the characters created have lives of their own. In a

\footnotetext{
${ }^{44}$ Wordsworth, Selected Poems and Prefaces, 446.

45 Margaret A. Syverson, The Wealth of Reality: An Ecology of Composition (Carbondale: Southern Illinois University Press, 1999), 9.

${ }^{46}$ Syverson, The Wealth of Reality, 28-74.
}

BOSS: The Biannual Online-Journal of Springsteen Studies 1.1 (2014) 
1999 interview with Patrick Humphries focusing on Tracks, Springsteen elaborates on the complexity of creating characterdriven work that is for the most part the product of the artist's imagination:

I think it calls for the listener to take a step back and realize that they're listening to a creation of some sort, a work of imagination. That what you're doing, part of your craft, is understanding - and you may be singing through the voice of another character to create that understanding.

I've written in many, many different voices-of which a listener will say that's obviously not literally your life...

Occasionally, I write something that's more autobiographical than not, but really it just goes all across the board. And I think that to over-interpret it, to overpersonalize it, is generally a mistake. As a writer you're paid to use your imagination, and your emotions, and your eyes, to create something that is real-in the sense that there's real emotion. And I think that whatever you're writing about, you have to find yourself in there in some fashion. That's what makes the song work. ${ }^{47}$

Springsteen is working through the process of creating work that has a life for itself; it may be informed by his experiences and contain a significant amount of self in the form of a unique perspective, but once it is written down, the work itself becomes the important thing. The writer's history, life, and experiences at that moment of artistic creation are no longer as important as what is happening in the work. Springsteen again echoes Eliot, who argues that when a poet creates art, "[w]hat happens is a continual

\footnotetext{
${ }_{47}$ Patrick Humphries, Interview with Bruce Springsteen, from Record Collector, February 1999 in Talk About a Dream, 269.
}

BOSS: The Biannual Online-Journal of Springsteen Studies 1.1 (2014) 
surrender of himself as he is at the moment to something which is more valuable. The progress of an artist is a continual self-sacrifice, a continual extinction of personality." 48 For Eliot, "[p]oetry is not the turning loose of emotion, but an escape from emotion; it is not the expression of personality but an escape from personality. ... [S]ignificant emotion [should have] its life in the poem and not in the history of the poet." 49 Springsteen considers "real emotion" and Eliot considers "significant emotion" emerging from the writing itself, not from within the personality-or the history-of the writer. At the time of writing, authors must separate themselves from the subjects they are writing about. Springsteen and Eliot have both channeled emotions into the stories they create and the "many, many different voices" of their protagonists. Like Springsteen, Eliot's most famous poems are character-driven: "The Love Song of J. Alfred Prufrock" (1917), “Gerontion" (1920), “The Hollow Men" (1925), "The Journey of the Magi" (1927), the protagonists of Four Quartets (1935-1942), even the poems in Old Possum's Book of Practical Cats (1939). The original working title of The Waste Land was He Do the Police in Different Voices, borrowed from a line in Charles Dickens's last novel, Our Mutual Friend (18641865): "You mightn't think it, but Sloppy is a beautiful reader of a newspaper. He do the Police in different voices." ${ }^{50} \mathrm{He}$ Do the Police in Different Voices was an appropriate early title for The Waste Land for at least two reasons that are important for thinking about

\footnotetext{
48 Eliot, "Tradition and the Individual Talent," 26.

${ }^{49}$ Eliot, "Tradition and the Individual Talent," 30.

50 T. S Eliot, The Waste Land; A Facsimile and Transcript of the Original Drafts Including the Annotations of Ezra Pound., ed. Valerie Eliot, (New York: Harcourt Brace Jovanovich, 1971), 4; Charles Dickens, Our Mutual Friend (London: Penguin Classics, 1998), 198.
}

BOSS: The Biannual Online-Journal of Springsteen Studies 1.1 (2014) 
Springsteen's many voices. First, the poem is rife with voices: the unnamed protagonist, Marie, the hyacinth girl, Madame Sosotris, a couple talking about nerves, women in the pub, and Tiresias, to name a few. Second, the title calls attention to the illiterate and anonymous lower classes of society, those who are normally not represented in high art. Indeed, as David Chinitz notes, for Eliot "popular culture was significant as both influence and subject. ... The Waste Land would have openly established popular culture as a major intertext of modernist poetry if [Ezra] Pound had not edited out most of Eliot's popular references." 51 In the manuscript of The Waste Land, the early draft titled He Do the Police in Different Voices starts with the lines "First we had a couple feelers down at Tom's place / There was old Tom, boiled to the eyes, blind," which anticipates the later pub passage that Eliot kept in the final version:

Now Albert's coming back, make yourself a bit smart.

He'll want to know what you done with that money he gave you

To get yourself some teeth. He did, I was there.

You have them all out, Lil, and get a nice set, He said, I swear, I can't bear to look at you. And no more can't I, I said, and think of poor Albert, He's been in the army four years, he wants a good time, And if you don't give it him, there's others will, I said. Oh is there, she said. Something o' that, I said. Then I'll know who to thank, she said, and give me a straight look. ${ }^{52}$

\footnotetext{
${ }^{51}$ David Chinitz, "T. S. Eliot and the Cultural Divide," PMLA 110:2 (March, 1995): 241-42.

52 Eliot, The Waste Land; A Facsimile and Transcript of the Original Drafts Including the Annotations of Ezra Pound., 4; Eliot, The Waste Land, 11.139-158; T. S. Eliot, T. S. Eliot: Collected Poems, 1909-1962, (New York: Harcourt Brace Jovanovich, 1991), 58.
}

BOSS: The Biannual Online-Journal of Springsteen Studies 1.1 (2014) 
These are the voices of London's lower-class, sitting in a pub near closing time, anticipating Lil's husband Albert's imminent return from World War I, debating how to tell Albert that the money he left for her to fix her teeth was used for an abortion. Eliot presents the conversation with a tone and diction he considers consistent with those of lower-class London. Gregory S. Jay suggests Eliot's "often affectionate imitation of [lower-class] voices ... conveys a respect for ... ordinary lives and feelings." 53 Chinitz highlights this affection in a passage from The Waste Land:

O City City, I can sometimes hear

Beside a public bar in Lower Thames Street,

The pleasant whining of a mandoline

And a clatter and a chatter from within

Where fishmen lounge at noon ${ }^{54}$

The words "pleasant," "clatter," and "chatter" indicate an affection for the working-class people in this public bar. But, like many of Eliot's modernist protagonists, the protagonist of The Waste Land is alienated from this interior. There may be affection for the workingclass, but there is no connection. Conversely, if this were on Nebraska or The Ghost of Tom Joad, the protagonists would be in a bar, drinking, and Springsteen would tell their stories rather than describe sounds heard through the walls.

Eliot's use of lower-class voices in The Waste Land is similar to Springsteen's adoption of working-class voices and Wordsworth's assertions about the role of the poet and the subjects of poetry. In the 1802 version of his "Preface to Lyrical Ballads,"

\footnotetext{
${ }^{53}$ Gregory S. Jay, "Postmodernism in The Waste Land: Women, Mass Culture, and Others," in Rereading the New: A Backward Glance at Modernism, ed. Kevin J. H. Dettmar (University of Michigan Press, 1992), 237.

${ }^{54}$ Eliot, The Waste Land, 11. 259 - 263; Eliot, T. S. Eliot, 63.
}

BOSS: The Biannual Online-Journal of Springsteen Studies 1.1 (2014) 
Wordsworth warns against poets who use high diction and elevated language. For Wordsworth, doing so only results in separating authors from their potential audience. 55 Rather, Wordsworth's poems contain, as he claims, "a selection of language really used by men ... Humble and rustic life was generally chosen ... because in that condition of life our elementary feelings coexist in a state of greater simplicity, and, consequently, may be more accurately contemplated, and more forcibly communicated." 56 Wordsworth uses the language of the common citizen because he believes that common language holds an authenticity and resonance that elevated language or rhetoric cannot. For example, consider the "The Thorn," a poem in which the protagonist (a retired sea captain) is talking to another, speculating about the history of a decrepit thorn tree at the top of a hill. In telling the story of the tree, the sea captain is encouraged to tell the story of Martha, a women engaged to a man named Stephen who, after getting Martha pregnant, marries another woman. Bereft, lost, and seemingly mad, Martha wanders the landscape alone, her fate and the fate of her baby mostly unknown until the interlocutor demands it:

"But what's the Thorn? and what the pond?

And what the hill of moss to her?

And what the creeping breeze that comes

The little pond to stir?"

"I cannot tell; but some will say

She hanged her baby on the tree;

Some say she drowned it in the pond.

Which is a little step beyond:

55 Wordsworth, Selected Poems and Prefaces, 447.

56 Wordsworth, Selected Poems and Prefaces, 446-447.

BOSS: The Biannual Online-Journal of Springsteen Studies 1.1 (2014) 
But all and each agree,

The little Babe was buried there,

Beneath that hill of moss so fair." 57

The language of Wordsworth's protagonist and interlocutor is simple, containing mostly short words, none of which has more than two syllables. The phrases are direct and frank. Though containing "simple and unelaborated expressions," the poem subtly conveys the feelings and psychology of its protagonist and subject. ${ }^{58}$ The thorn is much more than a tree; it is a space of mourning, forever entwined with the story of Martha and her dead child.

Springsteen would write similarly frank, predominantly monosyllabic, and deceptively simple lines nearly two hundred years later in dozens of songs, such as "Nebraska," "Johnny 99," and "Galveston Bay." On each of these and many similar tracks the narrative is set in a certain geographical space: Lincoln, Nebraska; Mahwah, New Jersey; Seabrook, Texas. Each geographical location becomes a code for a larger socio-cultural issue. Lincoln, a "town" in "Nebraska" instead of city, rising out of the plains, signifies desolation. Mahwah, which once boasted the largest auto assembly plant in the country, signifies economic downturn. Seabrook, a town of harbors where Clear Lake merges with Galveston Bay, signifies disruption. In Springsteen's more Romantic songs, natural settings carry similar levels of signification as they did to the Romantic poets: a river valley signifies youth ("The River"); a hill top signifies hierarchy ("Mansion on the Hill”); moonlight signifies hope ("Downbound Train"). In 1997, Springsteen told Nicholas

57 Wordsworth, Selected Poems and Prefaces, 73.

58 Wordsworth, Selected Poems and Prefaces, 446-447.

BOSS: The Biannual Online-Journal of Springsteen Studies 1.1 (2014) 
Dawidoff, "I had an interest of writing about the country - all of it. I was creating intimate portraits of individuals that you can draw back from and look at them in the context of the country they live in. You have to find circumstances where those characters resonate with psychological, emotional, and, by implication, political issues." 59 By the mid-1990s, Springsteen had become proficient at writing lyrics that made connections between an environment (context) and the kinds of stories (circumstances) that could be told about people in those spaces. The power in his songs comes in the interplay of these two key lyrical structures: context and circumstance.

Wordsworth was a master at connecting context and circumstance to lead to psychological resonance. ${ }^{60}$ In the "Preface to Lyrical Ballads," Wordsworth argues that the poet

considers man and the objects that surround him as acting and re-acting upon each other, so as to produce an infinite complexity of pain and pleasure; he considers man in his own nature and in his ordinary life as contemplating this with a certain quantity of immediate knowledge, with certain convictions, intuitions, and deductions, which from habit acquire the quality of intuitions; he considers him as looking upon this complex scene of ideas and sensations, and finding everywhere objects that immediately excite in him sympathies. ${ }^{61}$

59 Nicholas Dawidoff, "The Pop Populist," The New York Times Magazine, January 26, 1997, accessed June 2014, http:/ / www.nytimes.com/1997/01/26/magazine/the-pop-populist.html. 60 Jack Stillinger, "Introduction," in Selected Poems and Prefaces by William Wordsworth, ed. Jack Stillinger (Boston: Houghton Mifflin, 1965), xiv.

${ }^{61}$ Wordsworth, Selected Poems and Prefaces, 455.

BOSS: The Biannual Online-Journal of Springsteen Studies 1.1 (2014) 
According to Wordsworth, a poet illuminates the nuanced, emotional, and symbiotic relationship between a person and the objects surrounding that person. Context-ordinary context - is of ultimate importance. Only when considering people in their ordinary natural spaces can a poet reveal a person's value system and the immediate emotions emerging from being in a particular space at a particular time. "Once again / Do I behold these step and lofty cliffs, / That on a wild and secluded scene impress / Thoughts of a more deep seclusion," Wordsworth writes at the beginning of "Lines Composed a Few Miles Above Tintern Abbey."62 The ordinary context of a view over the River Wye when mixed with the protagonist's psyche results in the emotional response. Garman suggests that Springsteen uses "working-class geographies to illustrate the dissolution of working-class communities" that leads to an inability to "forge a collective working-class identity which provides people with a sense of self-worth." 63 The factories in "Johnny 99," "Factory," and "Youngstown" are not just physical objects. Rather, they are icons of a fragmented American dream. Or, as poet James Wolcott once quipped, "Silent factories are to [Springsteen] what church ruins were to the English Romantics, crumbling theaters of decay which serve as houses of lost faith." 64

But, rather than the mere presentation of American icons, Springsteen also engages in pointed social commentary. By adopting the voices of ordinary citizens he advocates for those who have been forgotten. During his interview with the Paris media,

\footnotetext{
62 Wordsworth, Selected Poems and Prefaces, 108.

${ }^{63}$ Bryan K. Garman, "The Ghost of History: Bruce Springsteen, Woody Guthrie, and the Hurt Song," Popular Music \& Society 20 (Summer, 1996): 85.

64 James Wolcott, "The Hagiography of Bruce Springsteen," Vanity Fair, December 1985 in Racing in the Street, 126.
}

BOSS: The Biannual Online-Journal of Springsteen Studies 1.1 (2014) 
Springsteen summarized his oeuvre this way: "My work has always been about judging the distance between American reality and the American dream - how far it is at any given moment." He draws on the debilitating home life of his childhood, looking "toward not just the psychological reasons in [his] house, but the social forces that played upon [his] home and made life more difficult."65 In his SXSW talk, Springsteen walks the audience through his experience listening to Hank Williams, spin after spin on the turntable, trying to figure out what made Williams's music important for him (and society) at that moment. Finally, his "ears became accustomed to its beautiful simplicity, and its darkness and depth." 66 Springsteen saw himself reflected in the characters populating Williams's songs. He found themes with which he wanted to engage. But country, as he remarks, was "rarely politically angry, and it was rarely politically critical. And I realized that that fatalism had a toxic element." 67 No one in country music was asking why things were the way they were, which was something Springsteen started doing in the early 1980s after reading Henry Steel Commanger and Allen Nevins's History of the United States. While reading this book, Springsteen told a Paris audience, he "started to learn about how things got to be the way they are today, how you end up a victim without even knowing it. And how people get old and just die after not having hardly a day's satisfaction or peace of mind in their lives." 68 Springsteen wanted to know what contributes to creating a state of mind that accepts stagnation. Country music depicted stagnation, but never

\footnotetext{
65 Springsteen, "An American in Paris."

66 Springsteen, "Bruce Springsteen's SXSW 2012 Keynote Speech."

${ }^{67}$ Springsteen, "Bruce Springsteen's SXSW 2012 Keynote Speech."

${ }^{68}$ Marsh, Glory Days, 36.
}

BOSS: The Biannual Online-Journal of Springsteen Studies 1.1 (2014) 
questioned why, according to Springsteen. Guthrie was asking those questions: "Woody's gaze was set on today's hard times. But also, somewhere over the horizon, there was something. Woody's world was a world where fatalism was tempered by a practical idealism. It was a world where speaking truth to power wasn't futile, whatever its outcome." 69 In "Tradition and the Individual Talent," T.S. Eliot argues that artists who wish to remain significant must have an "historical sense[, which] involves a perception, not only of the pastness of the past, but of its presence.... This historical sense, which is a sense of the timeless as well of the temporal, is what makes a writer traditional."70 In The Waste Land, Eliot incorporates texts ranging from Ovid's Metamorphosis to popular Ziegfeld Follies. By weaving together fragments of the works of antiquity with elements of Modernist popular culture and ideology, Eliot is arguing that all texts, regardless of their time of origin, can-and should-be looked to when considering contemporary concerns. He insists that to be traditional a "poet must develop or procure the consciousness of the past and ... should continue to develop this consciousness throughout his career." 71

As an artist, Springsteen has continued to develop his own consciousness of the past, and at each stage in his education he has attempted to incorporate into his writing and music what he has uncovered. For example, when choosing songs for We Shall Overcome: The Seeger Sessions Springsteen specifically chose songs that he could "make 'of the moment' ... so you're connected to this

\footnotetext{
69 Springsteen, "Bruce Springsteen's SXSW 2012 Keynote Speech."

${ }^{70}$ Eliot, "Tradition and the Individual Talent," 23.

${ }^{71}$ Eliot, "Tradition and the Individual Talent," 25.
}

BOSS: The Biannual Online-Journal of Springsteen Studies 1.1 (2014) 
present world."72 In the liner notes to The Seeger Sessions, Springsteen recalls the time in 1997 when he brought home a dozen Seeger records that transformed his understanding of folk music and its musical potential. For The Seeger Sessions, Springsteen describes seeking out stories he could "add [his] two cents to as an interpreter," something he suggests he has "done only very rarely in the past."73 Springsteen's interpretation of songs on The Seeger Sessions often includes shifting them to a minor key and adding blues, Cajun, or other rhythms, but his most significant updating comes in his version of "How Can a Poor Man Stand Such Times and Live?" Blind Alfred Reed originally recorded the song on December 4, 1929, as a response to the Great Depression. His version ends with the following lines:

Well, the doctor comes around with a face all bright, And he says in a little while you'll be all right.

All he gives is a humbug pill,

A dose of dope and a great big bill -

Tell me how can a poor man stand such times and live? ${ }^{74}$ Springsteen's version takes Reed's last verse and builds from there:

"Me and my old school pals had some mighty high times down here

And what happened to you poor black folks, well it just ain't fair"

He took a look around, gave a little pep talk, said "I'm with you" then he took a little walk

Tell me how can a poor man stand such times and live?

\footnotetext{
${ }^{72}$ Dave Marsh, "Will It Go Round in Circles," from Backstreets, 2006, in Talk About a Dream, 328.

73 Marsh, "Will It Go Round in Circles," 329.

${ }^{74}$ Blind Alfred Reed, "How Can A Poor Man Stand Such Times And Live" (1929), accessed June 2014, http:/ / archive.org/details/Reed.
}

BOSS: The Biannual Online-Journal of Springsteen Studies 1.1 (2014) 
Springsteen's version presents an indictment of the George W. Bush administration's handling of the aftermath of Hurricane Katrina. The second and third verses are inspired by news reports of Bush's photo-op filled visit to New Orleans in the days after the devastating flooding in 2005. Along with the power that comes from using common language and emotional description in ways consistent with Wordsworth's approach to writing, the lines allude to the corruption described in Reed's original:

Most our preachers preach for gold and not for souls

That's what keeps a poor man always in a hole

We can hardly get our breath

Taxed and schooled and preached to death

Tell me how can a poor man stand such times and live?

By using Reed's last verse as his first, Springsteen signals that the song will be an extension of the original song's decrying of economic conditions and shows his appreciation for what Eliot described as "not only of the pastness of the past, but of its presence."75 In Reed's version, the doctor is an active contributor to the financial inequality discussed in the song, an inequality felt by many of those who were victims of the flooding. In Springsteen's version, "the doctor" is President Bush, whose bright, happy face is that of a shyster promising healing but leaving only bills. The anachronism present in the work succeeds in placing the song on a historical continuum, blending the traumas of the past with those of the present, allowing the listener to understand a lineage of suffering and perceptions of an ineffective government, making it seem like the whole history of blues and suffering, in Eliot's words, "has a simultaneous existence and composes a simultaneous order" in the space of just one song. ${ }^{76}$

\footnotetext{
75 Eliot, "Tradition and the Individual Talent," 23.

${ }^{76}$ Eliot, "Tradition and the Individual Talent," 23.
}

BOSS: The Biannual Online-Journal of Springsteen Studies 1.1 (2014) 


\section{Springsteen, Authenticity, and Legacy}

When Springsteen broaches the subject of authenticity in his SXSW keynote, he is likely taking a jab at - or at the very least, refuting - those who have questioned his authenticity. Springsteen has continually challenged the perception that his enormous net worth and celebrity status contradict the messages of his songs. As he told Ed Bradley on 60 Minutes in 1995, "I believe that your fundamental point of view and politics comes out of some core emotional and psychological picture and is established by your early experience of life."77 When Springsteen appeared on the covers of Time and Newsweek in 1975 he was labeled a corporate stooge; when he released Born in the U.S.A. he was labeled a sellout; when he married Julianne Philips he was cast as out of touch with his New Jersey roots; when Sony released the Wal-Mart exclusive version of his greatest hits (which Springsteen agreed was a mistake) he was accused of going against the communitybased principles and labor advocacy he has espoused throughout his career. ${ }^{78}$ Scholars of popular culture have wrestled with Springsteen's authenticity for decades, noting and/or questioning any or all of the following: his humble roots, slow rise, major breakthroughs, various appropriations, personal decisions, rebirth post-9/11, concert performances, and political and marketing decisions. ${ }^{79}$ Indeed, there's hardly an article, interview, or

77 “Springsteen," 60 Minutes, January 21, 1996, accessed June 2014, http://www.youtube.com/watch?v=UjXAn_zQHpo\&feature=youtube_gdata_ player.

78 On Springsteen's regret of the Walmart release, see: Jon Pareles, "The Rock Laureate," The New York Times, February 1, 2009, accessed June 2014, http://www.nytimes.com/2009/02/01/arts/music/01pare.html.

79 Simon Frith, Music for Pleasure: Essays in the Sociology of Pop (New York: Routledge, 1988); Elizabeth Bird, “'Is That Me, Baby?' Image, Authenticity, and

BOSS: The Biannual Online-Journal of Springsteen Studies 1.1 (2014) 
broadcast that does not adhere to this narrative or, like the 60 Minutes and Paris interviews, ask Springsteen to reveal his authenticity by discussing how his roots have affected his psyche. In 1984, Springsteen told Kurt Loder, "I realized that I was a rich man, but I felt like a poor man inside." 80 Springsteen echoed that sentiment in "Better Days," confessing, "It's a sad funny ending to find yourself pretending / A rich man in a poor man's shirt."

My goal here, however, is not to rehash these claims; such discussions are important contributions to understanding Springsteen and his work within a post-modern context, but they are beyond my scope. Nor is my goal to question the authenticity of Springsteen as he presents his SXSW address. That is, I am not interested in making an argument about whether or not

the Career of Bruce Springsteen," American Studies 35:2 (1994): 39-57; Wolcott, "The Hagiography of Bruce Springsteen;" Lawrence Grossberg, "Rockin' with Reagan, or the Mainstreaming of Postmodernity," Cultural Critique 10 (October 1, 1988): 123-49; Michael R. Hemphill and Larry David Smith, "The Working American's Elegy: The Rhetoric of Bruce Springsteen," in Politics in Familiar Contexts: Projecting Politics through Popular Media, ed. Robert L. Savage and Dan D. Nimmo (Norwood, New Jersey: Ablex Pub, 1990), 199-214; John J. Sheinbaum, "'I'll Work for Your Love': Springsteen and the Struggle for Authenticity," in Reading the Boss, 223-242; Jefferson Cowie and Lauren Boehm, "Dead Man's Town: 'Born in the USA,' Social History, and Working-Class Identity," in Bruce Springsteen, Cultural Studies and the Runaway American Dream, ed. Kenneth Womack, J. Jerome Zolten, and Mark Bernhard (Burlington, Vermont: Ashgate, 2012), 25-44; Donna M Dolphin, “'Believe Me, Mister': The Tradition of Woody Guthrie's Hurt Song in Springsteen's," in Bruce Springsteen, Cultural Studies and the Runaway American Dream, 45-60; Elizabeth M. Seymour, "Where Dreams Are Found and Lost': Springsteen, Nostalgia, and Identity," in Bruce Springsteen, Cultural Studies and the Runaway American Dream, 61-78.

${ }^{80}$ Kurt Loder, "The Rolling Stone Interview: Bruce Springsteen on 'Born in the U.S.A.,'" Rolling Stone, December 6, 1984, accessed June 2014, http:/ / www.rollingstone.com/music/news/the-rolling-stone-interviewbruce-springsteen-on-born-in-the-u-s-a-19841206? print=true.

BOSS: The Biannual Online-Journal of Springsteen Studies 1.1 (2014) 
Springsteen at the podium is an accurate version of Springsteenthe-artist or one manufactured to maintain a real or imagined narrative of Springsteen as man of the people. And, as is readily apparent, Springsteen's conception of the working class (as is Wordsworth's, for that matter) is an idealized, nostalgic, romanticized, and problematic depiction of a group of people who are significantly more diverse than he suggests. Jefferson Cowie and Lauren Boehm as well as Elizabeth Seymour engage with these ideas thoroughly in their scholarship. ${ }^{81}$

Rather, I am interested in testing the limits of Springsteen's definition of authenticity as it moves from creativity and influence to legacy. Springsteen's definition of authenticity is very much consistent with how we as a society have come to define something as authentic. According to Lindholm, there are "two overlapping modes for characterizing any entity as authentic: genealogical or historical (origin) and identity or correspondence (content). Authentic objects, persons, and collectives are original, real, pure; they are what they purport to be, their roots are known and verified, their essence and appearance are one." 82 In this setting, Springsteen positions what he calls "the genesis and power of creativity" within a definition of authenticity that exists within a known and verifiable lineage of influence - doing very much what Shumway describes when he writes, "A genealogy of rock authenticity would look at jazz, folk, and pop music as the

\footnotetext{
${ }^{81}$ Cowie and Boehm, “Dead Man's Town”; Seymour, "Where Dreams Are Found and Lost."

${ }^{82}$ Lindholm, Culture and Authenticity, 2.
}

BOSS: The Biannual Online-Journal of Springsteen Studies 1.1 (2014) 
determining elements of its family tree." 83 Yet, how far into the work of and principles espoused by the artists should that lineage extend? Should it stay within the songs themselves or should it bleed into their social and political goals? What impact should Springsteen's definitions of creativity and authenticity have on his legacy? Springsteen has clearly decided to let the social and activist influences of artists like Woody Guthrie and Pete Seeger affect the way he positions his work and himself as an artist and a human being. The presence of food banks at concerts, which Springsteen encourages concertgoers to donate to, is just one example of how Springsteen blends his personal beliefs with advocacy. At some point he decided to become the living embodiment of Guthrie's and Seeger's legacies. Robert Santelli suggests that whenever Springsteen sings "This Land is Your Land" he becomes "a part of the ongoing story of American music and its role in enriching American culture." ${ }^{84}$ Springsteen maintains that role at the close of his SXSW talk when, in true Pete Seeger fashion, he encourages the audience to sing along with the chorus of "This Land is Your Land." In doing so, he succeeds in making Guthrie's words, and Seeger's efforts at keeping these words alive, meaningful for those in the audience.

More interesting, however, is the verse from "This Land is Your Land" Springsteen chooses to sing: the so-called controversial fourth verse, which argues against the idea of land and resources made private by the rich. The verse was inspired by Guthrie's

\footnotetext{
83 Springsteen, "Bruce Springsteen's SXSW 2012 Keynote Speech"; David R. Shumway, "Authenticity: Modernity, Stardom, and Rock \& Roll," Modernism/modernity 14:3 (2007): 529.

84 Robert Santelli, This Land Is Your Land: Woody Guthrie and the Journey of an American Folk Song (Philadelphia: Running Press, 2012), 243.
}

BOSS: The Biannual Online-Journal of Springsteen Studies 1.1 (2014) 
experiences seeing poor people employed to work at reduced wages on huge swaths of land owned by the wealthy. ${ }^{85}$ At Seeger's insistence, Springsteen and Seeger sang the fourth and fifth verses at Obama's first inauguration. That was the first and only other (known) time Springsteen has sung the fourth verse in front of an audience; my research reveals that in concert he has only sung the less controversial first three verses. Springsteen's decision to sing the fourth verse instead of the less controversial verses may have been a nod to the legacy of Guthrie, who was being celebrated that year at SXSW. But, it also leads one to question how fully Springsteen embodies the ideals the verse aspires to promote: the free and open exchange and use of cultural resources. Read metaphorically, the verse is about any property one group of owners withholds from others, be they land owners or, say, the recording industry. When considered within Springsteen's SXSW keynote assertion that successful theft (or influence) as creative inspiration is an important part of what makes one authentic, it is hard not to make a connection between the verse he sings and what Springsteen advocates in his talk. Kirby Ferguson, writer and director of the Everything's a Remix documentary series, argues that creativity contains three main elements: copying, transforming, and combining. ${ }^{86}$ To borrow Springsteen's terminology, we copy the ideas of our teachers and influences (which he did as a young musician copying Elvis, the Beatles, Joe Cocker, Van Morrison, and Dylan); once we are confident, we transform them into something new (which is how "Don't Let Me Be Misunderstood" becomes

\footnotetext{
85 Santelli, This Land Is Your Land, 81.

86 Kirby Ferguson, Everything Is a Remix Part 3, 2011, accessed June 2014, http://vimeo.com/25380454.
}

BOSS: The Biannual Online-Journal of Springsteen Studies 1.1 (2014) 
"Badlands"); and then combine multiple ideas to create something new and exciting (such as the blending of genres on Seeger Sessions and Wrecking Ball). When the creative process is allowed to flourish - that is, when expressions of ideas (such as lyrics) are free to be used by many - culture benefits. When they are not - that is, when owners lock expressions of ideas away-culture suffers. This is in part why Santelli writes that Springsteen is "enriching American culture" when he sings "This Land is Your Land." By passing on the song, Springsteen is also passing on the legacies of Guthrie and Seeger as well as the ideals upon which the song was founded.

Seeger has written, "I have spent a life 'borrowing' others' ideas. I really can't object if people borrow some of mine. I am glad if someone can improve my songs." 87 In the introduction to the second edition of How to Play the 5-string Banjo, Seeger gives permission to "reprint, whenever needed." 88 In a 1957 letter to Lynn Riggs, Seeger describes the pride he takes when others sing or reprint his songs, which he gives permission to do. He laments the fact that he was finally persuaded to "copyright the various songs I have either written new words to, or music, or both - in order to keep them from being restricted by the Broadway pirates. But it is one thing to copyright in order to prevent restrictions upon it, and another thing to copyright a song in order to restrict it." 89 Seeger understood when a singer passes a song on from one generation to the next, the singer is giving a gift to that generation's

\footnotetext{
87 Seeger, Where Have All the Flowers Gone, 15.

88 Pete Seeger, How To Play The 5-String Banjo, (Woodstock, New York: Music Sales America, 1992), 2.

${ }^{89}$ Rob Rosenthal and Sam Rosenthal, eds., Pete Seeger: In His Own Words (Boulder, Colorado: Paradigm Publishers, 2012), 275.
}

BOSS: The Biannual Online-Journal of Springsteen Studies 1.1 (2014) 
culture. He also understood that copyright, which was designed to protect culture and not corporate interests, was being transformed into an institution that protects corporations at the expense of culture..$^{90}$ He embodied the idea that music is a process of change over time, through which musicians build on and transform the work of prior artists, resulting in music that is no longer by just one person; it is music by the people "because so many folks have had a hand (or a throat) in shaping them." 91 He actively sought to reform the International Public Domain to ensure original artists whose work has passed into the public domain, but has been adapted by new artists, receive a percentage of the future royalties. Seeger's goal was to combat a musical colonialism of songs from poorer areas and nations that one day will "be collected and new words put to them in some wealthy city somewhere. The povertystricken village will stay poverty stricken." 92 In other words, Seeger was consistent in his approach to folk music and his ideals about preserving a folk process.

Springsteen's legacy as a musician has been solidified. His legacy as a cultural ambassador advocating for the arts is just beginning. In his SXSW talk, Springsteen emphasizes "it's the power and purpose of your music that still matters" for one to be considered authentic. ${ }^{93}$ The purpose of one's music extends beyond the lyrics and the score. It extends to how artists position themselves in relation to the social institutions designed to structure the lives of citizens. Springsteen has shown his power and

\footnotetext{
90 Siva Vaidhyanathan, Copyrights and Copywrongs: The Rise of Intellectual Property and How It Threatens Creativity (New York: New York University Press, 2003).

${ }^{91}$ Seeger, Where Have All the Flowers Gone, 146.

92 Rosenthal and Rosenthal, Pete Seeger, 280-282.

93 Springsteen, “Bruce Springsteen's SXSW 2012 Keynote Speech."
}

BOSS: The Biannual Online-Journal of Springsteen Studies 1.1 (2014) 
purpose by advocating for gay marriage as early as 1996, by speaking out against the wars in Iraq and Afghanistan, by lending his voice to the 2014 Shoah Foundation fundraising gala, to name only a few instances. When Jon Landau supported high prices for concert downloads, he noted they were consistent with what Pearl Jam and Phish have been charging. ${ }^{94}$ More purposeful and powerful might have been to offer downloads for free, looking to artists like Radiohead, Nine Inch Nails, and Coldplay, who have bypassed labels and released albums for free or on a pay-what-youwant basis. Nine Inch Nails encourages fans to remix tracks and upload them to the band's web site, cementing a direct connection between fans and artist and making an argument about the anachronism of a label-centric recording industry. Perhaps Springsteen might do that with an upcoming album. Or let fans pay what they can afford for concert audio. As BruceFunds has brought to light, many fans do not have the means to pay for a ticket and many others have the means to donate..$^{95}$ I suspect many do not have the means to pay for concert downloads, either. By asking fans to pay and by creating two tiers of audio quality (MP3 and the more expensive FLAC), Springsteen and his management team recreate the social hierarchies Springsteen rails against in his songs.

Springsteen has reached a stage in his career where people actively seek him out as the conscience of society. During his interview with the Paris media, one reporter observed, "so many

\footnotetext{
${ }^{94}$ Andy Green, “The Inside Story of Bruce Springsteen's Official Live Downloads," Rolling Stone, accessed June 2014, http:/ / www.rollingstone.com/music/news/the-inside-story-of-brucespringsteens-official-live-downloads-20140207.

95 "Love \& Gratitude," Bruce Funds, accessed June 2014, http://brucefunds.org/love--gratitude.html.
}

BOSS: The Biannual Online-Journal of Springsteen Studies 1.1 (2014) 
people these past couple years look to you for your interpretation of events. ... so many people care about what you think, and what you feel about what is happening in the world." 96 Robert Santelli has suggested that "Springsteen was America in the eyes of his fans and much of the world." 97 The last decade has seen Springsteen transform from rock and roll singer to social critic. Springsteen's SXSW talk puts him in a lineage that includes some of the most important writers and thinkers to defend traditional or authentic processes for creating art (what Eliot defines as traditional; Springsteen labels authentic). If he made a statement in favor of the free flow of information (as Seeger did in his defense of the public domain and as Springsteen's lawyers' are doing by pointing scholars to the Fair Use Doctrine for quoting his lyrics), people would listen. Something might change. It might put him on a path toward removing himself from the corporate structures that actively attempt to limit the creative processes Springsteen advocates. It would reinforce his commitment to a traditional and authentic approach to composing that encourages artists to borrow from their influences without the fear of repercussion that stagnates artistic growth. It would show Springsteen continuing his journey to embrace fully Guthrie's and Seeger's influences, to adopt fully the traditional, folk-infused creative process he illuminates in his SXSW keynote address, and to emerge fully as a cultural ambassador for the arts.

\footnotetext{
${ }^{96}$ Springsteen, "An American in Paris."

${ }^{97}$ Santelli, This Land Is Your Land, 244.
}

BOSS: The Biannual Online-Journal of Springsteen Studies 1.1 (2014) 